\title{
Differences in the secretion pattern of growth hormone and insulin-like growth factor - I in sheep of two crossbreeds after dietary protein restriction ${ }^{*}$
}

\author{
A. Wójcik-Gladysz' ${ }^{1}$ P. Krejérí and J. Polkowska ${ }^{1}$ \\ 'The Kielanowski Institute of Animal Physiology and Nutrition, \\ Polish Academy of Sciences \\ 05-110, Jablonna, Poland \\ 'Institute of Animal Physiology and Genetics, \\ Crech Academy of Sciences \\ 104-00, Uhrinerves, Czech Republic
}

(Received 23 March 2002; tevised version 30 August 2002; accepted 11 October 2002)

\section{$\triangle B S T R A C T$}

The presented study was designed to evaluate the relationships between cross types of lambs and the pattern of GH and IGF-I secretion under conditions of standard and restricted protein feeding. The experiment was performed on two different cross types of female lambs: [(Merino x Romanov) $x$ Suffolk], $n=10,(M \times R)$ and $[($ Merino $\times$ Finn $) \times$ Suffolk $], n=9,(M \times F)$. Lambs of both cross types were divided into two groups and fed on two isoenergetic diets, but containing different protein levels, for 16 weeks, starting at 6 montlis of age. $A t$ the end of the experimental fecding blood samples were taken over a period of 6 hours at 10-min intervals. The concentrations of $\mathrm{GH}$ and IGF-I were estimated by adioiminunological method, the parameters of $\mathrm{GH}$ release pulsatility were calculated using the Pulsar computer program. The basal level of GH and IGF-J were significantly $(\mathrm{P}<0.05$ ) higher in MxR compared to MxF lambs. The higher $\mathrm{GH}$ level in MxR lambs was associated with significant elevation $(\mathrm{P}<0.05)$ of $\mathrm{GH}$ pulsc amplitude. Long-term feeding on the restricted protein diet in both cross types caused a significant $(\mathrm{P}<0.05)$ increase of mean $\mathrm{GH}$ concentrations and $\mathrm{GH}$ pulse amplitude, higher in MxR lambs, but had no effect on the IGF-I level. In conclusion, the basal secretion of GH and JGF-I could be dependent on the genetic background of the cross-bred lambs. $\mathrm{GH}$ secretion can be modulated by the protcin level in the diet, with the intensity of the changes depending on the basal GH level.

KEY WORDS: sheep, crossbrecd, growth hormone, insulin-like growth factor-l, dietary protein

\footnotetext{
* Supported by State Committee for Scientific Research, Grant No. 5 PO6E 02410 and Czech Committee (GAČR), Grant No. 523/99/0603
} 


\section{INTRODUCTION}

For many years selective breeding of domestic animals has been used for the purpose of obtaining high utility features in existing breeds. Sheep are selectively bred, and crossbreeding is further used to obtain animals that are highly prolific, meaty, and with good wool quality. The most popular breed of sheep in Poland is Polish Merino, which is bred for its wool. The others are Romano sheep and Finn sheep, breeds characterised by their high prolificacy, or Suffolk sheep for their meatiness (Rzepecki at el., 1997). Nowadays, most commercial sheep are crosses between the above-mentioned pure breeds. The commercially most important trait in sheep breeding is growth.

Normal growth depends on sequential activation of crucial genes during development and throughout adult life and is under the control of multiple endocrine, neuroendocrine and environmental factors. The endocrine control of growth involves a complex of interactions of several hormones and growth factors, acting both systemically and locally. They create the endocrine system, which is called the somatotrophic axis. The most important hormones essential for growth are growth hormone $(\mathrm{GH})$, secreted by the pituitary cells, and IGF-I, which acts as the second messenger of GH metabolic action (Breier and Gluckman, 1991, reviewed by Bertherat et al., 1995).

Growth hormone is secreted in a random pulsatile pattern in ruminants and other species. Variation in the secretion pattern can be affected by the physiological status of animals, age, fceding conditions and genetic background (Bertherat et al., 1995; Gatford et al., 1997). Different levels of endogenous GH in blood can refiect genetic differences among animals related to obtaining crossbreeds of high breeding value. For example, the high plasma level of GH in dairy cattle is related to selection aimed at enhanced milk production (Grochowska et al., 1998). However, the secretion of GH and IGF-I in crossbred animals has only been studied in cattle and horses, not in sheep (Malinowski et al., 1996; Matsuzaki et al., 1998; Grochowska ct al., 2001). It is known that in sheep, some traits like growth rate or fertility are determined to a high degree by genetics (Bertherat et al., 1995).

One of the factors affecting the $\mathrm{GH}$ level is nutrition, especially dietary restrictions. Limitation of feed energy intake increases the synthesis and release of $\mathrm{GH}$ in adult ovariectomized sheep (Thomas et al., 1991). Chronic restrictions of protein also augment the mean plasma concentration of $\mathrm{GH}$ in growing femalc lambs (Polkowska et al., 1996; Gładysz et al., 2001). The response of IGF-I to dietary manipulations, especially under long-term conditions, is less known. IGF-I mediates the anabolic actions of GH in peripheral tissues (Daughaday and Rotwein, 1989) and appears to be an important factor in the regulation of protein metabolism (McGuire et al., 1992).

The presented study was designed to evaluate: 1 . the effect of sheep breed cross type on the pulsatile pattern of GH secretion and IGF-I secretion and 2. the effect of long-term feeding of a protein restricted diet on the secretion of these hormones. 


\section{MATERIAL AND METHODS}

\section{Animals and experimental procedure}

The experiment was performed on two types of crossbred female lambs [(Merino $\times$ Romano $) \times$ Suffolk], $n=10,(\mathrm{MxR})$ and [(Merino $\times$ Finn $) \times$ Suffolk], $\mathrm{n}=9,(\mathrm{MxF})$ born in the first two weeks of March. There were three sires, the same for two cross-types used in the experiment. At 6 months of age all lambs reached a similar body weight of about $30 \mathrm{~kg}$. The animals were put into individual pens and maintained under natural lighting conditions with water available ad libitum. Lambs of both types were further divided into two groups that for a period of 16 weeks received one of two isoenergetic dicts but containing different protein levels: restricted $(R), 8 \%$ of protein in diet; $(\mathrm{MxR} n=5, \mathrm{MxF} n=6)$; standard (S), 18\%, (MxR $\mathrm{n}=5, \mathrm{MxF} n=3)$. In both dicts the composition of minerals and vitamins was the same and the net energy value was equal to $5 \mathrm{MJ} / \mathrm{kg} \mathrm{DM}$ (Table 1). Daily rations were divided into 2 equal meals given at about 07.00 and $13.00 \mathrm{~h}$. The daily feed allowance $(\mathrm{kg})$ was $9.8 \%$ of the metabolic body weight $\mathrm{BW}-\mathrm{kg}^{0.75}$ adjusted every two weeks for the current body weight. The animals were weighed every two weeks.

TABLE 1

Composition of diets, $\%$

\begin{tabular}{lcc}
\hline Feeds & Restricted dict & Standard diet \\
\hline Meadow hay & 6.52 & 33.1 \\
Oat straw & 33.33 & 6.47 \\
Soyabean meal & 0.00 & 25.23 \\
Dried sugar beet pulp & 60.00 & 35.05 \\
Mineral mixture "Polfamix" & 0.15 & 0.15 \\
Crude protein & 8 & 18 \\
Net energy MJ/kg DM & 5 & 5.5 \\
\hline
\end{tabular}

composition of "Polfamix" in g/kg: vit. E, 1.5; Fe, 0,$5 ; \mathrm{Zn}, 2,5 ; \mathrm{Mg}, 6,5 ; \mathrm{Co} .0 .015 ; \mathrm{Mn}, 3,0$ : $\mathrm{J}, 0,01 ; \mathrm{Sc}, 0,003 ; \mathrm{Na}, 60,0 ; \mathrm{Ca}, 240 ; \mathrm{P}, 120$

At the end of 16 weeks of experimental fecding ( $42^{\text {nd }}$ week of age), jugular venous blood samples were taken from each lamb via indwelling catheters at 10 -min intervals over a 6 -hour period. Blood samples were centrifuged and plasma was collected and stored at $-20^{\circ} \mathrm{C}$ until analysis.

During the entire experiment a veterinarian regularly inspected the animals. All procedures of the experiment were approved by the Ethics Committce at The Kielanowski Institute of Animal Physiology and Nutrition in Jabłonna, according to the Polish Guide for the Care and Use of Animals (August 2, 1997) 


\section{Growth hormone radioimmunoassay}

Plasma GH was assayed in duplicate by double-antibody RIA according to Staba et al. (1994) using pituitary-derived bGH, purified by chromatography on SE-Sephadex C-50 in sodium acetate buffer for iodination and reference standards. The first antibody was produced in rabbits against pituitary derived bGH NIDDKGH-B-1003A. The assay detection limit was $0.68 \mathrm{ng} / \mathrm{ml}$ plasma samples. The intra-assay and inter-assay coefficients of variation (CV) averaged 5.9 and $10.2 \%$, respectively.

\section{$I G F-$ I radioimmunoassay}

Plasma IGF-I was determined by double-antibody RIA, according to a modified procedure described by Daughaday et al. (1980). Extraction of samples was performed using acidified ethanol and cryoprecipitation according to Justova and Hána (1993). Efficiency of extraction was approximately $80 \%$. Antibody against IGF-l was prepared and kindly donated by Dr. G.S.G. Spencer (Ruakura Agricultural Center, New Zealand, 1987). Recombinant IGF-I (Calbiochem, La Jolla, USA) was used for iodination and as the standard. Iodinated IGF-I was prepared by using the standard chloramine-T method. The detection limit was $0.6 \mathrm{ng} / \mathrm{ml}$ and the intraassay $\mathrm{CV}$ and the inter-assay $\mathrm{CV}$ were 7.3 and $10.2 \%$, respectively.

\section{Statistical analysis}

Data are presented as mean \pm SEM, statistical significance was defined at the $\mathrm{P}<0.05$ level. Pulse characteristics of GH were calculated using the Pulsar Computer Program developed by Merriam and Watcher (1982) and adapted to operate on an IBM-PC. The cut-off parameters $G_{(n)}$ were set to a $5 \%$ error rate assuming normal data distribution. $G(1)=3.98, G(2)=2.40, G(3)=1.68, G(4)=1.24$, $\mathrm{G}(5)=0.93$. Analysis was performed individually for cvery ewe, and included the entire sampling period. The measured frequencies of $\mathrm{GH}$ pulses were defined as the number of identified pulses per 6-h collection period and expressed as a mean \pm SEM. The differences in GH concentrations were analysed by one-way analysis of variance (ANOVA), and in the frequency of GH pulses was calculated using the ANOVA rank Kruskal-Wallis test (Statistica ${ }^{\mathrm{TM}} \mathrm{PL}$ computer program, StatSoft $\mathbb{B}$ ) Kraków, Poland). IGF-I parameters were calculated for each sheep and compared in groups by one-way analysis of variance using the Statistica TMPL computer program. Comparisons between groups were made using the Mann-Whitney test (Statistica). 


\section{RESULTS}

The initial body weight at the age of 6 months was similar for all lambs and reached about $30 \mathrm{~kg}$. The final body weight after 16 weeks of experimental feeding on the $\mathrm{S}$ diet did not differ between cross types of lambs $(45.8 \pm 5.4 \mathrm{~kg}$ for $\mathrm{MxR}$ and $46.0 \pm 3.2 \mathrm{~kg}$ for $\mathrm{MxF}$ ). After feeding on the $\mathrm{R}$ diet the final body weight of two cross types was also similar, but lower than of the lambs on the $S$ diet $(40.6$ $\pm 5.4 \mathrm{~kg}$ for $\mathrm{MxR}$ and $40.5 \pm 1.9 \mathrm{~kg}$ for $\mathrm{MxF}$ ).

TABLE 2

Changes of GH parameters in peripheral blood plasma in crossbred lambs of two types fed the standard diet. Data were calculated using Pulsar analysis. Data are presented as mean values $\pm \mathrm{SEM}$

\begin{tabular}{|c|c|c|}
\hline Cross-breed & $\mathrm{M} \times \mathrm{R}$ & $M \times F$ \\
\hline Mean $\mathrm{GH} n g / \mathrm{ml}$ & $4.8 \pm 1.0^{\circ}$ & $2.4 \pm 0.1^{\mathrm{b}}$ \\
\hline Number of pulses $\mathrm{n} / 360 \mathrm{~min}$ & $7.8 \pm 1.7$ & $8.7 \pm 1.1$ \\
\hline Pulse amplitude ng/ml & $5.1 \pm 2.1^{4}$ & $1.5 \pm 0.2^{b}$ \\
\hline Inter-pulse interval min & $51.1 \pm 12.6$ & $43.8 \pm 6.1$ \\
\hline
\end{tabular}

a,b $\mathrm{P}<0.05$

The parameters of pulsatile release of $\mathrm{GH}$ in two cross types of lambs fed on the standard diet are given in Table 2. Both cross types of lambs differed in mean GH concentrations, which were significantly higher $(\mathrm{P}<0.05)$ in $\mathrm{MxR}$ than in $\mathrm{MxF}$ sheep (Figure 1a). This response was associated with an increase in GH pulse amplitude $(5.1 \pm 1.7 \mathrm{vs} 1.5 \pm 0.2 \mathrm{ng} / \mathrm{ml}$ ) (Figure $1 \mathrm{~b}$ ). The general pattern of GH secretion, that is to say, the number of pulses and pulse intervals, in both cross types was similar. Long-term feeding on diet $\mathrm{R}$ caused a significant $(\mathrm{P}<0.05)$ increase in mean $\mathrm{GH}$ concentrations and pulse amplitudes in both cross types. The response to diet $\mathrm{R}$ was stronger in MxR lambs; the mean GH concentration and pulse amplitude were about twice as high in MxR than in the MxF lambs.

Both experimental cross types differed in the IGF-I level $(\mathrm{P}<0.05)$, which was higher in MxR compared with MxF sheep (50.3 \pm 11 vs $27.7 \pm 3 \mathrm{ng} / \mathrm{ml}$ ). Feeding the $R$ protein diet did not have any influence on the level of this hormone in any of the types (Figure 2).

\section{DISCUSSION}

The results of the present study have shown a clear effect of cross type of lambs on the secretion pattern of GH and IGF-I. Particularly high variability was observed in mean levels of $\mathrm{GH}$, which was associated with significant differences in $\mathrm{GH}$ pulse amplitude in these crossbreeds. Since all sheep used in the experiment were 
a)

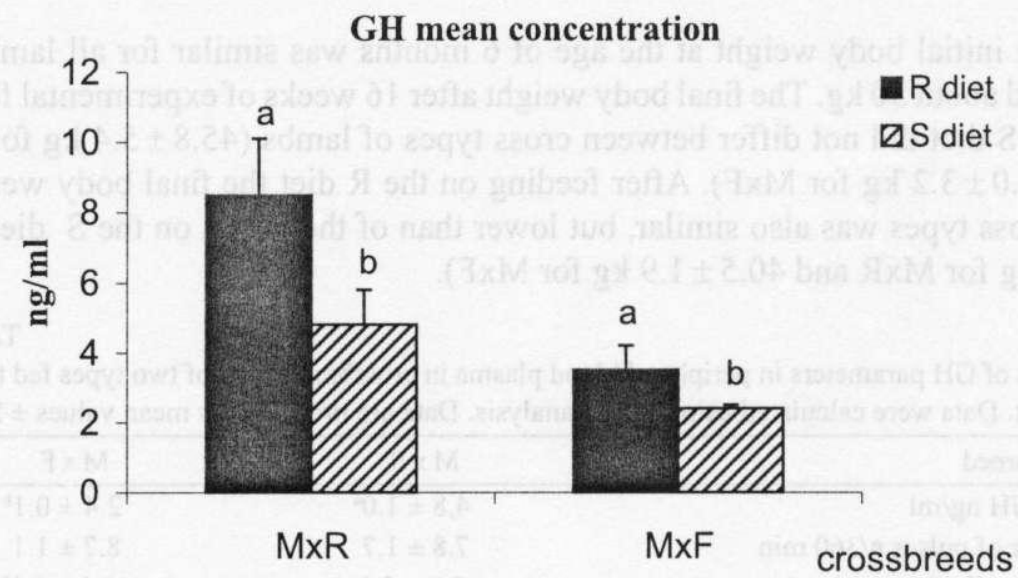

b)

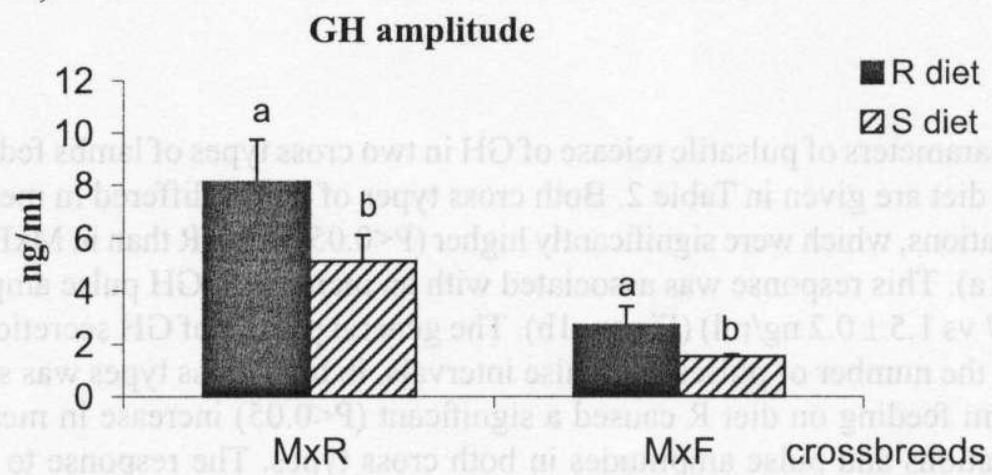

Figure 1. The differences in the secretion. Mean concentration (a) and mean amplitudes (b) of GH in the blood plasma of lambs from two different cross types fed on $\mathrm{S}$ and $\mathrm{R}$ diet. Means \pm SEM with different typescripts $(a, b)$ differ at $P<0.05$. The same number over bars marked the statistical significance between them

of the same age and weight and kept under the same conditions, the differences in $\mathrm{GH}$ concentrations and pulse amplitude could most probably be due to differences in genetic background. These results correspond well with the observations of Matsuzaki et al. (1998) and Grochowska et al. (2001) in cattle. In both studies distinct relationships between the basal level of GH and IGF-I and breed were found. The dependence of the hormonal level on genetic background was also observed in reference to the concentrations of prolactin and insulin in the blood plasma of cattle (Matsuzaki et al., 1997). Also, large differences in the basal plasma level of IGF-I were found in two different horse breeds (Malinowski et al., 1996). The fact 


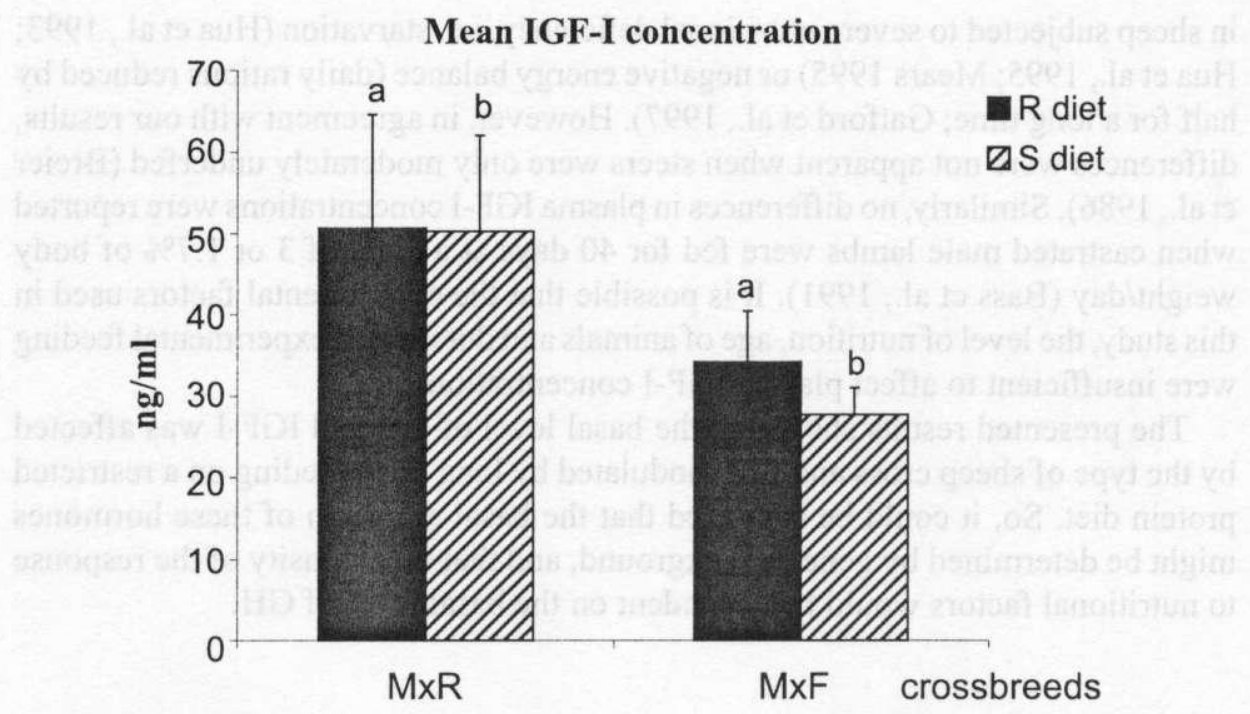

Figure 2. The differences in the secretion. Mean concentration of IGF-I in the blood plasma of lambs from two different cross types fed on $\mathrm{S}$ and $\mathrm{R}$ diet. Means $\pm \mathrm{SEM}, \mathrm{P}<0.05$

that genetic background can determine the basal level of GH in blood plasma was confirmed by studies in which a single mutation in the gene coding $\mathrm{GH}$ was sufficient to change the level of this hormone (Schlee et al., 1994; Furlan et al., 1998).

So far, there has been no definite answer as to what extent environmental conditions rather than genetic background cause this variability. In many studies the influence of diet on the GH level in blood has been emphasized (reviewed by Thorner et al., 1995). For example, in adult sheep, restriction in energy intake increased plasma GH levels (Foster et al., 1989; Thomas et al., 1991). Furthermore, restriction of protein in diets of growing sheep resulted in augmentation of $\mathrm{GH}$ secretion (Polkowska et al., 1996; Gładysz et al., 2001).

It is noteworthy in the present study that sheep from both cross types responded to limitation of protein in the diet in a similar way, but the intensity of this response depended on the basal GH level for the cross type. In this case the increase in plasma $\mathrm{GH}$ concentration was due to a rise in pulse amplitude. The enhanced secretion of $\mathrm{GH}$ resulting from limited nutrition is thought to maintain metabolic homeostasis by conserving body proteins and mobilizing fatty acids from adipose tissue (Vance et al., 1992).

In contrast to other reports (Mears, 1995), we failed to observe any effect of protein restriction in diets on plasma IGF-I concentrations. Nutritional status affects IGF-I in ruminants by depressing its plasma concentrations (McGuire et al., 1992). However, clear differences in circulating IGF-I concentrations were observed only 
in sheep subjected to severe nutritional deficiency, i.e. starvation (Hua et al., 1993; Hua et al., 1995; Mears 1995) or negative energy balance (daily rations reduced by half for a long time; Gatford et al., 1997). However, in agreement with our results, differences were not apparent when steers were only moderately underfed (Breicr et al., 1986). Similarly, no differences in plasma IGF-I concentrations were reported when castrated male lambs were fed for 40 days at a level of 3 or $1.7 \%$ of body weight/day (Bass et al., 1991). It is possible that the experimental factors used in this study, the level of nutrition, age of animals and duration of experimental feeding were insufficient to affect plasma IGF-I concentrations.

The presented results show that the basal level of GH and IGF-I was affected by the type of sheep cross and was modulated by long-term feeding on a restricted protein diet. So, it could be supposed that the basal secretion of these hormones might be determined by genetic background, and that the intensity of the response to nutritional factors would be dependent on the basal level of GH.

\section{ACKNOWLEDGEMENTS}

The authors are grateful to NHPP USA for the gift of bGH. We thank Dr. Stuart Spencer for his generous gift of anti-IGF-I antiserum.

\section{REFERENCES}

Bass J.J., Oldham J.M., Hodgkinson S.C., Fowke P.J., Sauerwein E., Molan P., Breier B.H., Gluckman P.D., 1991. Influence of nutrition and bovine growth hormone $(\mathrm{GH})$ on hepatic $\mathrm{GH}$ binding, insulin-like growth factor-I and growth of lambs. J. Endocrinol. 128, 181-186

Bertherat J., Bluct-Pajot M.T., Epelbaum J., 1995. Neuroendocrine regulation of growth hormone. Eur. J. Endocrinol. 132, 12-24

Breicr B.H., Gluckman P.D., 1991. The regulation of postnatal growth: nutritional influences on endocrine pathways and function of the somatotrophic axis. Livest. Prod. Sci. 27, 77-94

Breier B.H., Bass J.J., Butter J.H., Gluckman P.D., 1986. The somatotrophic axis in young steers, influence of nutritional status on pulsatile release of growth hormone and circulating concentrations of insulin-like growth factor-I. J. Endocrinol. 111, 209-215

Daughaday W.H., Maris J.K., Blethen S.L., 1980. Inhibition of access of bound somatomedin to membrane receptor and immunobinding sites. A comparison of radioreceptor and radioimınunoassay of somatomedin in native and acid-ethanol-extract serum. J. Clin. Endocrinol. Metab. 51, 781-788

Daughaday W.H., Rotwein P., 1989. Insulin-like growth factors I and II. Peptide, messenger ribonucleic acid and gene structures, serum and tissue concentrations. Endocrine Rev. 10, 68-91 
Foster D.L., Ebling F.J.P., Micka A.F., Vannerson L.A., Bucholtz D.C., Wood R.I., Suttie J.M., Fenner D.E., 1989. Metabolic interfaces between growth and reproduction. I. Nutritional modulation of gonadotropin, prolactin and growth hormone secretion in the growth-limited female lamb. Endocrinology $125,342-350$

Furlan L.R., Givisiez P.E.N., Ferraz A.L.J., Lataro R.C., Chardulo L.A.L., Ferro J.A., Ferro M.I.T., 1998. Growth hormone polymorphism in Bos taurus x Bos indicus crossbreed beef cattle. Biotechnol. Agron. Soc. Environ. 2, 22 (Abstr.)

Gatford K.L., Quinn K.J., Walton P.E., Grant P.A., Hosking B.J., Egan A.R., Owens P.C., 1997. Ontogenic and nutritional changes in circulating insulin-like growth factor - I IGF-I., IGF-II and IGF-binding proteins in growing ewe and ram lambs. J. Endocrinol. 155, 47-54

Gładysz A., Krejči P., Šimůnek J., Polkowska J., 2001. Effect of central infusions of neuropeptide Y on the somatotropic axis in sheep fed on two levels of protein. Acta Neurobiol. Exp. 61, 255-266

Grochowska R., Snochowski M., Reklewski Z., 1998. Characteristics of growth hormone changes in peripheral blood in Polish Friesian cattle. Med. wet. 54, 119-122

Grochowska R., Sørensen P., Zwierzchowski L., Snochowski M., Løvendahl P., 2001. Genetic variation in stimulated GH release and in IGF-I of young dairy cattle and their association with the leucine/valine polymorphism in the GH gene. J. Anim. Sci. 79, 470-476

Hua K.M., Hodgkinson S.C., Bass J.J., 1995. Differential regulation of plasma levels of insulin-like growth factor-I and -II by nutrition, age and growth hormone treatment in sheep. J. Endocrinol. $147,507-516$

Hua K.M., Ord R., Kirk S., Li Q.J., Hodkinson S.C., Spencer G.S.G., Molan P.C., Bass J.J., 1993. Regulation of plasma and tissue levels of insulin-like growth factor-I by nutrition and treated with growth hormone in sheep. J. Endocrinol. 136, 217-224

Justová V., Hána V., 1993. Optimizing of IGF-I determination in serum and plasma (in Czech). Immunoassay 3, 43-49

Malinowski K., Christensen R.A., Hafs H.D., Scanes C.G., 1996. Age and breed differences in thyroid hormones, insulin like growth factor (IGF-I) and IGF binding protein in female horses. J. Anim. Sci. 74, 1936-1942

Matsuzaki M., Takizawa S., Ogawa M., 1997. Plasma insulin, metabolite concentrations, and carcass characteristics of Japanese Black, Japanese Brown and Holstein steers. J. Anim. Sci. 75, 3287-3293

Matsuzaki M., Sato T., Morita S., Shiba N., Tsuneishi E., Hara S., Ozutsumi K., Yamagichi T., 1998. Characteristics of somatotropic axis in Wagyu cattle. Biotechnol. Agron. Soc. Environ. 2, 22 (Abstr.)

McGuire M.A., Vicini J.L., Bauman D.E., Veenhuizen J.J., 1992. Insulin-like growth factors and binding proteins in ruminants and their nutritional regulation. J. Anim. Sci. 70, 2901-2910

Mears G.J., 1995. The relationship of plasma somatomedin IGF-I to lamb growth rate. Can. J. Anim. Sci. $75,327-331$

Merriam G.R., Wachter K.W., 1982. Algorithms for the study of episodic hormone secretion. Amer. J. Physiol. 243, E310 -E318

Polkowska J., Krejči P., Snochowski M., 1996. The long-term effect of low protein diet on the somatostatin hypothalamic neuronal system and the pituitary growth hormone cells in growing ewe. Exp. Clin. Endocrinol. 104, 59-66

Rzepecki R., Kania S., Radecka J., 1997. Estimation of breeding value of rams in the years 1995-1996 (in Polish). Research Institute of Animal Production, Kraków, XIII-XIV, 32-33

Schlee P., Graml R., Schallenberg E., Schams D., Rottmann O., Olbrich-Bludau A., Pirchner F., 1994. Growth hormone and insulin-like growth factor-I concentrations in bulls of various growth hormone genotypes. Theor. Appl. Genet. 88, 497-500 


\section{SECRETION OF GROWTH HORMONE AND GROWTH FACTOR-I IN SHEEP}

Slaba J., Krejči P., Skarda J., Huybrechts L.M., Decuypere E., Herrmann E., 1994. Plasma profiles of somatotropin and IGF-I in dairy cows following application of two preparations of recombinant bovine somatotropin in a sustained release vehicle. Physiol. Res. 43, 37-43

Spencer G.S.G., Hallett K.G., Fadlalla A.M., Spencer E.M., 1987. Temporal changes in the circulating levels of growth hormone, insulin, somatomedin-C and thyroxine in sheep during active immunization against somatostatin. Endocrinol. Exp. 21, 299-306

Thomas G.B., Cummins J.T., Francis E., Sudbury A.W., McCloud P.I., Clarke I.J., 1991. Effect of restricted feeding on the relationship between hypophysial portal concentrations of growth hormone $(\mathrm{GH})$-releasing factor and somatostatin, and jugular concentrations of $\mathrm{GH}$ in ovariectomized ewes. Endocrinology 128, 1151-1158

Thorner M.O., Hartman M.L., Vance M.L., Pezzoli S.S., Ampleford E.J., 1995. Neuroendocrine regulation of growth hormone secretion. Neurosci. Biobehav. Rev. 19, 465-468

Vance M.L., Hatrman H.J., Thorner M.O., 1992. Growth hormone and nutrition. Hormone Res. 38, Suppl. 1, 85-88

\section{STRESZCZENIE}

Różnice w pulsacyjnym uwalnianiu hormonu wzrostu i insulino-podobnego czynnika wzrostowego-I u jagniąt z dwóch typów mieszańców hodowlanych

Celem przedstawionej pracy było określenie wpływu różnych typów mieszańców owiec na charakterystykę uwalniania GH i IGF-I, przy stosowaniu diet izoenergetycznych o standardowej i obniżonej zawartości białka. Doświadczenia przeprowadzono na 6-miesięcznych jarkach mieszańcach: [(Merynos x Romanowska) x Suffolk], $\mathrm{n}=10,(\mathrm{MxR})$ oraz [(Merynos x Fińska) x Suffolk], n=9, (MxF). W obrębie każdej grupy rasowej zwierzęta podzielono na dwie grupy i przez 16 tygodni żywiono dietami o zróżnicowanym poziomie białka. Pod koniec żywienia doświadczalnego, przez 6 godzin w 10 minutowych odstępach pobierano krew z żyły jarzmowej. Koncentrację GH i IGF-I oznaczano metodą radioimmunologiczna, natomiast parametry pulsacyjnego uwalniania tego hormonu wykorzystując program komputerowy „Pulsar”. Podstawowy poziom GH i IGF-I był istotnie $(\mathrm{P}<0,05)$ wyższy u owiec $(\mathrm{MxR})$ w porównaniu z owcami $(\mathrm{MxF})$. Podwyższona koncentracja GH u owiec $(\mathrm{MxR})$ była wynikiem wzrostu $(\mathrm{P}<0,05)$ amplitudy pulsów tego hormonu. Długotrwałe żywienie dietą o obniżonym poziomie białka owiec obydwóch typów rasowych powodowało $(\mathrm{P}<0,05)$ wzrost średniej koncentracji GH oraz amplitudy pulsów; silniejsza odpowiedź wystapiła u owiec (MxR). Nie stwierdzono wpływu diety na poziom IGF-I. Można przypuszczać, że podstawowe poziomy GH i IGF-I są uwarunkowane genetycznie dla poszczególnych ras bądź ich mieszańców. Sekrecja GH może być modulowana przez poziom białka w diecie, a intensywność zmian sekrecji tego hormonu jest zależna od podstawowego poziomu GH. 